\title{
COMPARISON OF MODULY OF ELASTICITY OBTAINED BY NON- DESTRUCTIVE AND DESTRUCTIVE TESTS OF TIMBER SAMPLES
}

\author{
Marta Čukman \\ University of Zagreb, Faculty of Civil Engineering, student \\ Corresponding author: marta.cukman@gmail.com \\ Luka Jelenković \\ Kamgrad d.o.o., C.E. \\ Lucija Karaula \\ KP Konstrukcije, C.E. \\ Kristijan Krnjus \\ University of Zagreb, Faculty of Civil Engineering, student
}

Abstract: In this paper, we used non-destructive techniques (NDTs) and destructive techniques (DTs) to assess the mechanical properties of structure-sized timber members. The experiments included several NDTshygrometric, ultrasonic, and resistographic methods-as well as static bending and compression tests parallel to the grain. Using a linear regression model, we correlated the NDT and DT parameters.

Keywords: NDT, DT, modulus of elasticity, strength

\section{USPOREDBA MODULA ELASTIČNOSTI NA TEMELJU REZULTATA DOBIVENIH RAZORNIM I NERAZORNIM METODAMA ISPITIVANJA DRVENIH UZORAKA}

Sažetak: U radu se prikazuje usporedba rezultata dobivenih modula elastičnosti na temelju razornih (RM) i nerazornih (NRM) metoda ispitivanja uzoraka obične i lamelirane drvene građe. Istraživanje NRM se provodilo korištenjem vlagomjera, ultrazvuka i rezistografa, dok su se statička ispitivanja RM provodila u preši na tlak paralelno s vlakancima, te savijanjem. Odnosi RM i NRM dobiveni su korištenjem modela linearne regresije.

Ključne riječi: NRM, RM, modul elastičnosti, čvrstoća 


\section{INTRODUCTION}

It is now possible to examine old timber structures by using non-destructive techniques (NDTs). NDT instruments can now evaluate the physical and mechanical properties of timber, for example with ultrasonic methods, and detect internal defects by using electronic drilling resistance instruments.

NDT instruments have several advantages: they are simple to operate, relatively small, and compact during the transport. However, properly estimating the reliability of an NDT instrument requires measuring the variability of mechanical properties in timber elements. To assess the reliability of various NDTs, we researched samples of softwood and laminated timber, testing the strength parallel to the grain for old softwood (fir) and comparing those results with those for laminated timber and softwood. These experiments were performed at the Laboratory of the Faculty of Civil Engineering, University of Zagreb. Using NDTs, we measured the moisture content and stress wave speed (SWS), and then performed resistographic measurements to detect internal irregularities. We also performed bending tests and compression tests parallel to the grain. In this paper, we report on the testing equipment, our methodology for data processing and interpretation, and correlations of NDT parameters with the modulus of elasticity, based on a linear regression model.

\section{MATERIALS AND METHODS}

Experiments were performed on various samples of soft and laminated timber, as well as on old softwood, following the HRN EN 408 standard [1]. For the softwood, 4 samples were used for compression tests parallel to the grain (D1-D4), and 3 samples for bending tests (D5-D7). For the laminated timber, 12 samples were used for compression tests parallel to the grain (L1-L12), and 4 samples for bending tests (L5-L7). Three samples of old softwood were used for compression tests parallel to the grain (SD3A, SD3B, and SD4).

To compare the ultrasonic and resistographic results, we also investigated nonstandard samples of laminated timber (LM1, LV1), cross-laminated timber (XL1), and old softwood (SD1-SD4).

By visually inspecting samples of old prime-quality softwood, we found several shape irregularities and extended degradation of the base material on their lateral surfaces. We also found irregularities in these samples, such as knots, longitudinal splittings, cracks, biological damage, holes, and insect damage. Figure 1 shows the samples.

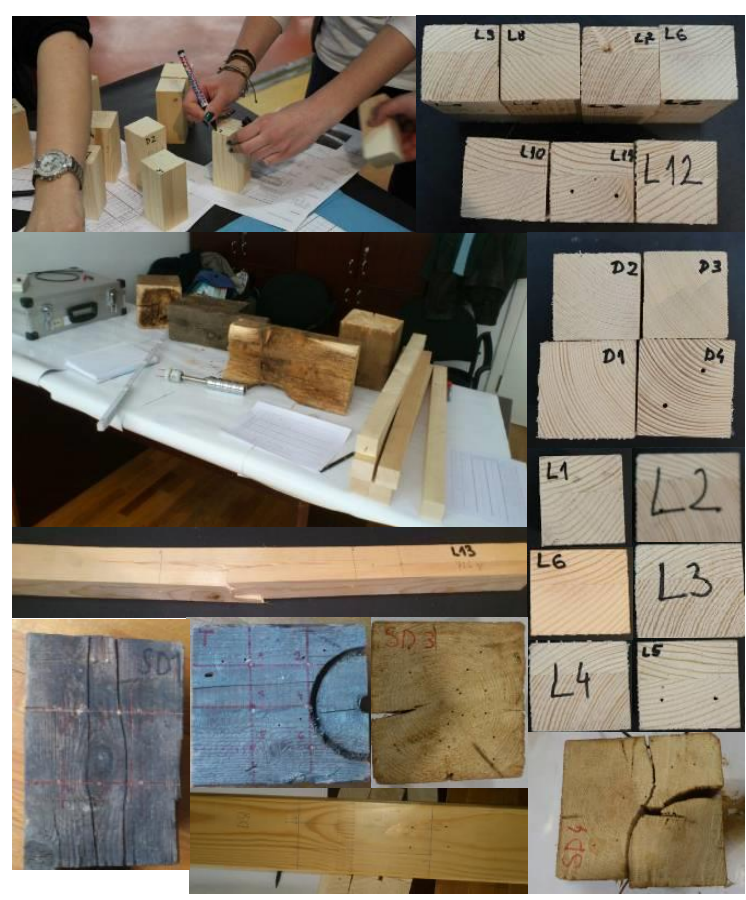

Figure 1 Performance limits for RC components 
We used the following NDTs in this research:

a) Hygrometric tests: Used to evaluate moisture content, which severely affects the mechanical properties of timber;

b) Ultrasonic investigations: Used to determine the relationship between the stress wave speed and the elastic properties of the timber;

c) Resistographic measurements: Used to evaluate the timber density by measuring the drilling resistance along the path of a small needle inserted into the timber.

We performed the following static tests to evaluate the stiffness, ultimate strength, and collapse mode:

a) Compression parallel to the grain;

b) Bending.

The next two chapters describe each method and its equipment, according to the descriptions from [2] and [3].

\section{NON-DESTRUCTIVE TESTS}

\subsection{Hygrometric tests}

The hygrometric tests were performed with a Vanicek VIVA 12, a digital pin-type resistance meter with built-in pins designed to precisely measure the moisture content of wood, up to $100 \%$ in increments of $0.1 \%$. The moisture content was measured for all samples. Figure 2 shows the hygrometric device.

\subsection{Ultrasonic investigations}

The ultrasonic tests were performed with a Sylvatest DUO, equipped with a data-acquisition unit and two transducers. We used the direct method, placing the transducers on opposite faces of the same specimen. The velocity of the ultrasonic pulse (stress wave speed) was determined based on the distance between the two transducers. We performed ultrasonic tests on all samples, using two procedures: 1) the direct method parallel to the grain; 2) the direct method perpendicular to the grain.

\subsection{Resistographic measurements}

The resistographic measurements were performed with an IMLRESI F500-S, a drilling-resistance measurement system, based on the energy needed to pierce a needle through the wood. These results are represented as graphic profiles of the drilling resistance of the timber specimens (soft). We performed resistographic measurements on all samples. Figure 3 shows one resistographic measurement.

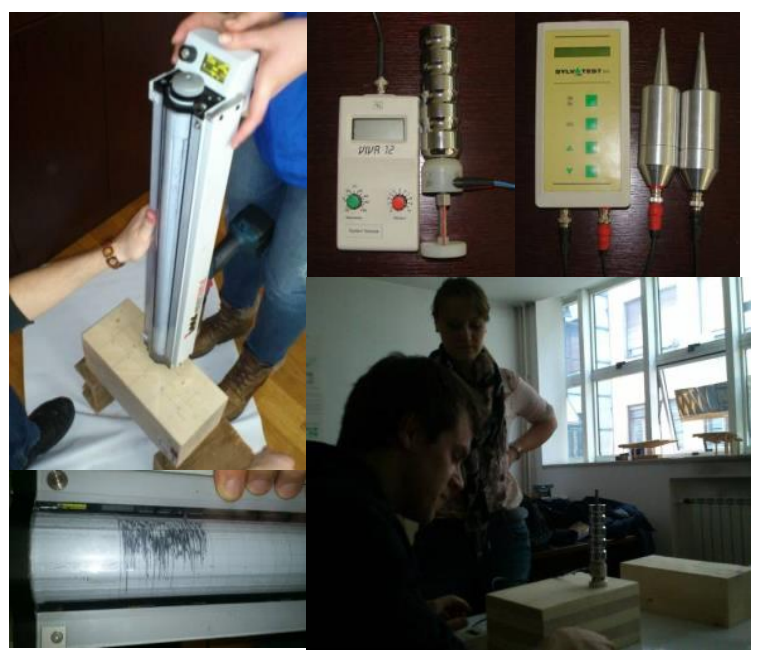

Figure 2 Measurements and devices; resistographic measurements (left) and hygrometric measurements (right) 


\subsection{Experimental results}

We analyzed the mean values of NDT measurements for the laminated timber (L1-L14, LV1, LM1), crosslaminated timber (XL1), softwood (D1-D7), and old prime-quality softwood (SD1-SD4). Tables 1-4 show the specimen names, dimensions, and mean values of the moisture content and stress wave speed (SWS).

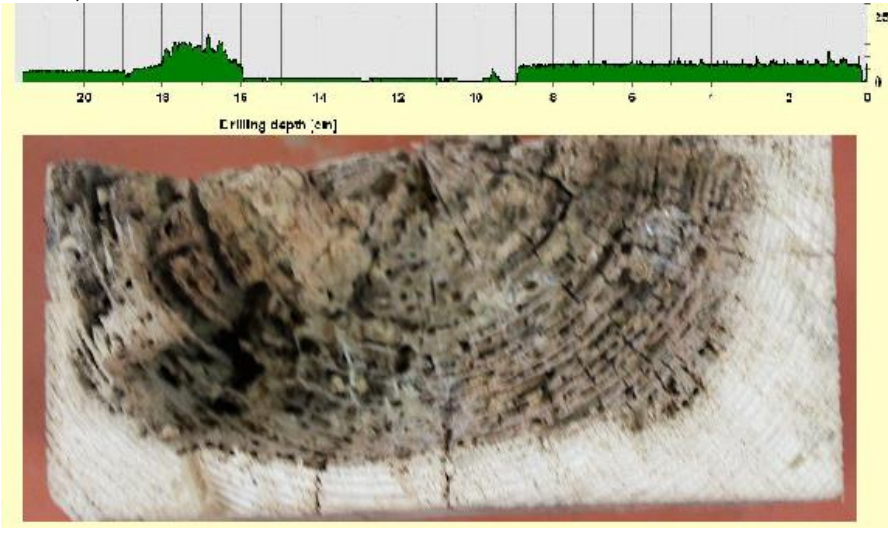

Figure 3 Resistographic measurement (SD2)

Table 1 Results of non-destructive tests on specimens L1-L14

\begin{tabular}{|c|c|c|c|c|c|c|c|}
\hline \multirow{3}{*}{ Spec. } & \multicolumn{3}{|c|}{ Dimensions [mm] } & \multirow{3}{*}{$\begin{array}{l}\text { Hygr. } \\
{[\%] M C}\end{array}$} & \multicolumn{3}{|c|}{ Ultrasonic [m/sec] } \\
\hline & \multirow{2}{*}{$b$} & \multirow{2}{*}{$h$} & \multirow{2}{*}{ I } & & \multirow{2}{*}{$\begin{array}{c}\text { SWS - L } \\
\text { Avg. }\end{array}$} & \multirow{2}{*}{$\begin{array}{c}\text { SWS - T } \\
\text { Avg. }\end{array}$} & \multirow{2}{*}{$\begin{array}{c}\text { SWS - } \mathbf{R} \\
\text { Avg. }\end{array}$} \\
\hline & & & & & & & \\
\hline L1 & 45.60 & 44.26 & 99.88 & 11.3 & 5101 & 620 & 689 \\
\hline L2 & 45.91 & 46.22 & 99.64 & 11.0 & 5259 & 1223 & 716 \\
\hline L3 & 44.74 & 45.41 & 100.01 & 11.1 & 5170 & 1032 & 759 \\
\hline L4 & 45.57 & 45.56 & 99.91 & 10.7 & 5180 & 947 & 665 \\
\hline L5 & 47.88 & 45.69 & 99.68 & 11.0 & 5521 & 1445 & 650 \\
\hline L6 & 45.27 & 44.32 & 99.80 & 10.9 & 5170 & 862 & 646 \\
\hline L7 & 45.50 & 45.66 & 99.10 & 12.1 & 5226 & 836 & 749 \\
\hline L8 & 46.60 & 44.97 & 99.86 & 10.8 & 5380 & 512 & 569 \\
\hline L9 & 44.64 & 45.15 & 99.66 & 10.7 & 5493 & 1054 & 918 \\
\hline L10 & 48.09 & 44.95 & 99.93 & 11.0 & 5530 & 1428 & 833 \\
\hline L11 & 48.13 & 44.70 & 99.82 & 10.6 & 5170 & 1336 & 811 \\
\hline L12 & 46.26 & 45.95 & 99.92 & 10.9 & 5657 & 969 & 558 \\
\hline L13 & 48.16 & 45.80 & 800.00 & 10.1 & 5499 & 1710 & 767 \\
\hline L14 & 46.23 & 46.27 & 800.00 & 11.3 & 5546 & 1133 & 608 \\
\hline L15 & 46.54 & 46.50 & 800.00 & 10.5 & 5659 & 743 & 736 \\
\hline L16 & 45.62 & 47.14 & 799.00 & 11.2 & 5826 & 907 & 1050 \\
\hline
\end{tabular}

Table 2 Results of non-destructive tests on specimens XL1, LV1, LM1

\begin{tabular}{|c|c|c|c|c|c|c|c|c|c|}
\hline \multirow{3}{*}{ Spec. } & \multicolumn{3}{|c|}{ Dimensions [mm] } & \multicolumn{3}{|c|}{ Hygr. [\%]MC } & \multicolumn{3}{|c|}{ Ultrasonic [m/sec] } \\
\hline & $h$ & $h$ & & Parallel & Perp. & Rad. & SWS - L & SWS - T & SWS - R \\
\hline & D & $n$ & 1 & Avg. & Avg. & Avg. & Avg. & Avg. & Avg. \\
\hline$X L 1$ & 200 & 130 & 297 & 11.1 & 12.1 & 12.9 & 4494 & 1061 & 3917 \\
\hline LV1 & 157 & 117 & 350 & 13.3 & 15.3 & 15.4 & 5645 & 1505 & 765 \\
\hline LM1 & 156 & 155 & 349 & 14.4 & 16.3 & 16.3 & 5562 & 1709 & 674 \\
\hline
\end{tabular}


Table 3 Results of non-destructive tests on specimens D1-D7

\begin{tabular}{|c|c|c|c|c|c|}
\hline \multirow{3}{*}{ Spec. } & \multicolumn{3}{|c|}{ Dimension [mm] } & \multirow{3}{*}{$\begin{array}{l}\text { Hygr. } \\
{[\%] \mathrm{MC}}\end{array}$} & \multirow{2}{*}{$\begin{array}{c}\text { Ultrasonic }[\mathrm{m} / \mathrm{sec}] \\
\text { SWS - L }\end{array}$} \\
\hline & \multirow{2}{*}{$b$} & \multirow{2}{*}{$h$} & \multirow{2}{*}{ I } & & \\
\hline & & & & & Avg. \\
\hline D1 & 50.04 & 49.43 & 99.72 & 15.8 & 6383 \\
\hline$D 2$ & 45.77 & 46.20 & 99.87 & 14.6 & 5544 \\
\hline D3 & 45.10 & 45.19 & 100.01 & 15.7 & 6233 \\
\hline$D 4$ & 49.05 & 49.69 & 99.91 & 12.1 & 5177 \\
\hline D5 & 45.48 & 45.43 & 799.00 & 16.6 & 5021 \\
\hline$D 6$ & 45.06 & 44.47 & 800.00 & 16.8 & 5546 \\
\hline D7 & 44.16 & 45.00 & 800.00 & 16.4 & 5949 \\
\hline
\end{tabular}

Table 4 Results of non-destructive tests on specimens SD1-SD4

\begin{tabular}{|c|c|c|c|c|c|c|c|c|c|}
\hline \multirow{3}{*}{ Spec. } & \multicolumn{3}{|c|}{ Dimensions [mm] } & \multicolumn{3}{|c|}{ Hygr. [\%]MC } & \multicolumn{3}{|c|}{ Ultrasonic [m/sec] } \\
\hline & & & & Parallel & Perp. & Rad. & SWS - L & SWS - T & SWS - R \\
\hline & D & $n$ & $T$ & Avg. & Avg. & Avg. & Avg. & Avg. & Avg. \\
\hline SD1 & 203 & 137 & 266 & 34.7 & 44.8 & 68.3 & 4502 & 416 & 483 \\
\hline SD2 (a) & 192 & 50 & 402 & 18.0 & 16.2 & 17.7 & & & \\
\hline$S D 2(b)$ & 192 & 25 & 402 & 20.0 & 6.0 & 19.0 & 4641 & 670 & 633 \\
\hline SD2 (c) & 192 & 65 & 402 & 17.0 & 17.3 & 17.2 & & & \\
\hline SD3 & 180 & 180 & 200 & 14.2 & 16.1 & 16.6 & 3831 & 670 & 866 \\
\hline SD4 & 180 & 180 & 183 & 14.2 & 47.7 & 16.3 & 5391 & 201 & 569 \\
\hline
\end{tabular}

\section{DESTRUCTIVE TESTS}

\subsection{Compression tests parallel to the grain}

The compression tests were performed using a force control loading device with a load capacity of $6000 \mathrm{kN}$. To determine the ultimate compression strength, we performed destructive tests in which the load was increased at a constant speed until the specimen failed. Typical failure patterns exhibited longitudinal fractures and crushed grains under the load point. Figure 4 shows timber samples after and during the experiment, and Table 5 shows the results.
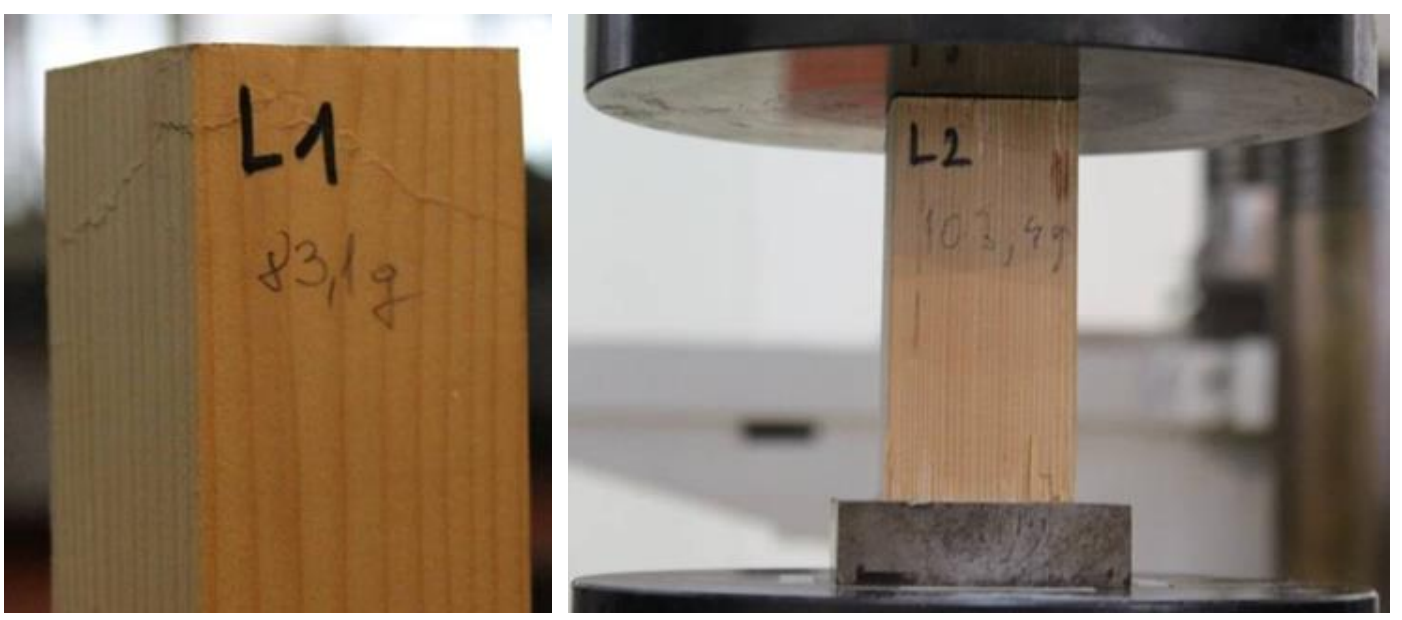

Figure 4 Compression tests after (left) and during (right) destructive testing 
Table 5 Results of destructive tests on specimens D1-D4; SD3A, SD3B, SD4; L1-L12

\begin{tabular}{|c|c|c|c|c|c|}
\hline \multirow{3}{*}{ Spec. } & \multicolumn{3}{|c|}{ Dimensions [mm] } & \multirow{3}{*}{$\begin{array}{c}\text { Load } \\
{[\mathrm{kN}]} \\
\text { Compr. }\end{array}$} & \multirow{3}{*}{$\begin{array}{l}\text { Compr. } \\
\text { strength } f_{c} \\
\text { [MPa] }\end{array}$} \\
\hline & \multirow{2}{*}{$b$} & \multirow{2}{*}{$h$} & \multirow{2}{*}{ I } & & \\
\hline & & & & & \\
\hline D1 & 50.04 & 49.43 & 99.72 & 145.40 & 58.78 \\
\hline D2 & 45.77 & 46.20 & 99.87 & 106.00 & 50.13 \\
\hline D3 & 45.10 & 45.19 & 100.01 & 116.10 & 56.97 \\
\hline D4 & 49.05 & 49.69 & 99.91 & 130.50 & 53.54 \\
\hline Avg. & 47.49 & 47.63 & 99.88 & 124.50 & 54.86 \\
\hline St.dev. & 2.42 & 2.27 & 0.12 & 17.18 & 3.83 \\
\hline$f_{c, 0, k}[M P a]$ & & & & & 50.64 \\
\hline SD3A & 50.90 & 50.80 & 101.70 & 96.60 & 37.36 \\
\hline$S D 3 B$ & 50.99 & 50.63 & 102.60 & 87.06 & 33.72 \\
\hline SD4 & 55.58 & 50.74 & 101.74 & 112.60 & 39.93 \\
\hline Avg. & 52.49 & 50.72 & 102.01 & 98.75 & 37.00 \\
\hline St.dev. & 2.68 & 0.09 & 0.51 & 12.91 & 3.12 \\
\hline$f_{c, 0, k}[\mathrm{MPa}]$ & & & & & 34.09 \\
\hline L1 & 45.60 & 44.26 & 99.88 & 99.88 & 49.49 \\
\hline L2 & 45.91 & 46.22 & 99.64 & 139.00 & 65.51 \\
\hline L3 & 44.74 & 45.41 & 100.01 & 126.40 & 62.22 \\
\hline L4 & 45.57 & 45.56 & 99.91 & 127.30 & 61.31 \\
\hline L5 & 47.88 & 45.69 & 99.68 & 110.50 & 50.51 \\
\hline L6 & 45.27 & 44.32 & 99.80 & 95.25 & 47.47 \\
\hline L7 & 45.50 & 45.66 & 99.10 & 107.90 & 51.94 \\
\hline L8 & 46.60 & 44.97 & 99.86 & 97.80 & 46.67 \\
\hline L9 & 44.64 & 45.15 & 99.66 & 131.90 & 65.44 \\
\hline L10 & 48.09 & 44.95 & 99.93 & 106.00 & 49.04 \\
\hline L11 & 48.13 & 44.70 & 99.82 & 105.50 & 49.04 \\
\hline L12 & 46.26 & 45.95 & 99.92 & 99.68 & 46.89 \\
\hline Avg. & 46.18 & 45.24 & 99.77 & 112.26 & 53.79 \\
\hline St.dev. & 1.24 & 0.62 & 0.24 & 14.91 & 7.49 \\
\hline$f_{c, 0, k}[\mathrm{MPa}]$ & & & & & 46.79 \\
\hline
\end{tabular}

\subsection{Bending tests}

For the bending tests, we used a force control testing machine with a load capacity of $6000 \mathrm{kN}$. Using a four-point static method, the tested beams were loaded with two symmetric, concentrated forces, applied at a third of the beam span by interposing a rigid steel profile between the actuator and the test specimen (Fig. 5). To determine the modulus of elasticity, we measured the deformation at the middle of the span until the applied load reached $40 \%$ of the assumed maximum load. The bending strength was obtained by increasing the load until the specimen failed. The results of destructive tests show the displacement $(w)$ as a function of applied force $(F)$.

Almost all specimens ruptured around large knots near the center of the tensile edge of the beam crosssection, which manifested in tearing of the most stressed fibers. 

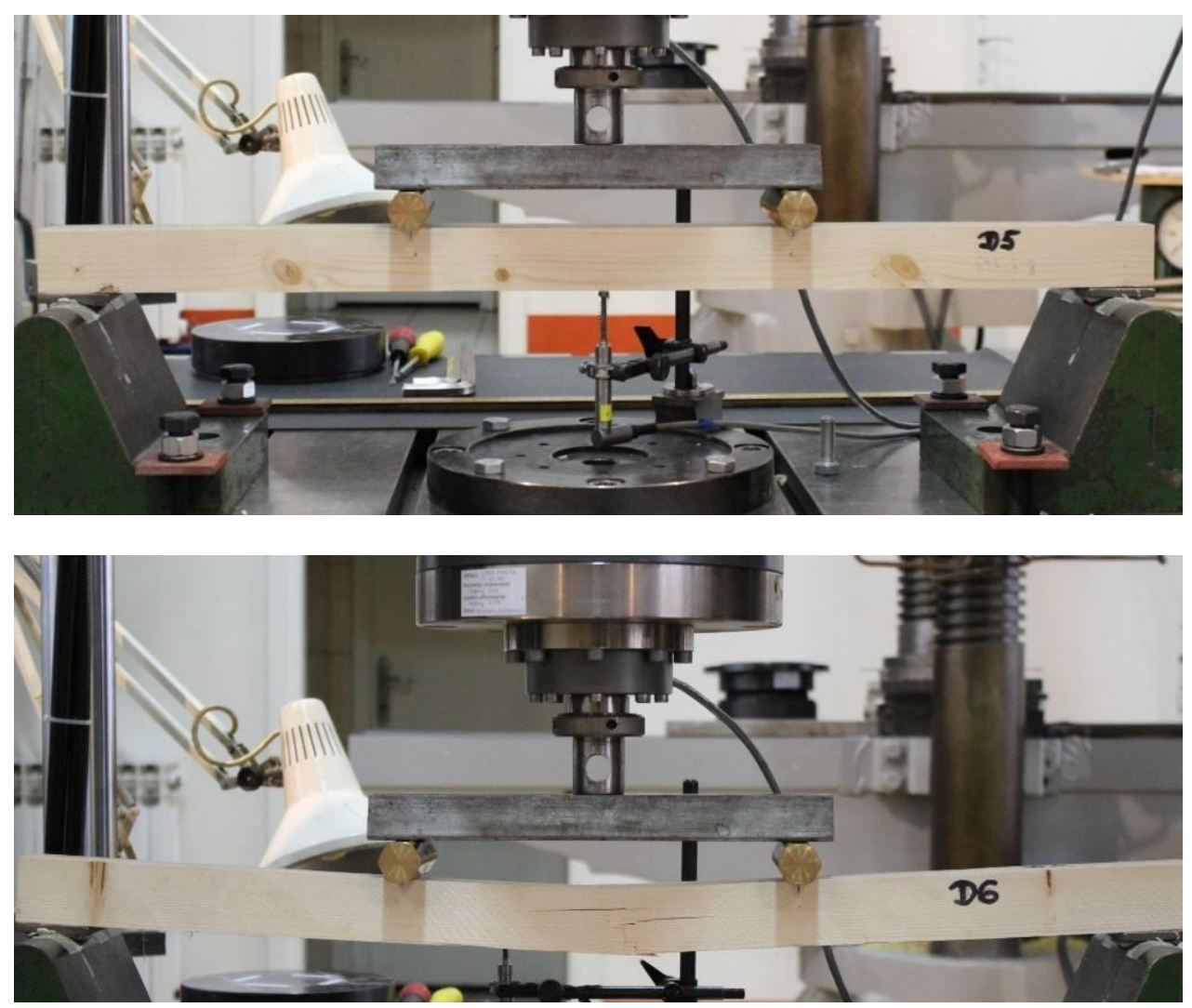

Figure 5 Bending tests

\subsection{Comparison of NDT and DT}

After our experiments, we compared the static and dynamic moduli of elasticity for specimens L13-L16 and D5D7. Tables 6-7 show the density, average stress wave speed (SWS), dynamic modulus of elasticity, static modulus of elasticity, and bending strength for these samples. Regression of dynamic modulus of elasticity on static modulus of elasticity are presented in Figures 6-9.

Table 6 Comparison of NDT and DT results for specimens L13-L14

\begin{tabular}{|c|c|c|c|c|c|c|}
\hline Spec. & $\begin{array}{l}\text { Density } \\
{\left[\mathrm{kg} / \mathrm{m}^{3}\right]}\end{array}$ & $\begin{array}{r}\text { SWS - L } \\
A v g .\end{array}$ & $\begin{array}{c}E_{\mathrm{dyn}} \\
{[\mathrm{MPa}]}\end{array}$ & $\begin{array}{c}E_{\mathrm{m}, \mathrm{g}} \\
{[\mathrm{Mpa}]}\end{array}$ & $\begin{array}{l}\text { Bending } \\
\text { strength } \\
f_{\mathrm{m}}[\mathrm{MPa}]\end{array}$ & $\begin{array}{c}\text { Corrected } \\
\text { bending } \\
\text { strength } \\
f_{\mathrm{m}}[\mathrm{MPa}]\end{array}$ \\
\hline L13 & 411.43 & 5499.00 & 12441.20 & 11600.57 & 43.97 & 38.23 \\
\hline L14 & 496.13 & 5546.00 & 15259.98 & 14505.96 & 78.35 & 68.13 \\
\hline L15 & 418.94 & 5659.00 & 13416.15 & 12174.10 & 38.81 & 33.75 \\
\hline L16 & 484.73 & 5826.00 & 16452.89 & 14772.64 & 43.81 & 38.10 \\
\hline \multicolumn{2}{|c|}{ Average } & 5632.50 & 14392.55 & 13263.32 & 51.24 & 44.55 \\
\hline \multicolumn{2}{|c|}{ St. dev. } & 145.43 & 1803.57 & 1609.69 & 18.24 & 15.86 \\
\hline \multicolumn{2}{|c|}{ CV } & 0.026 & 0.125 & 0.121 & 0.356 & 0.356 \\
\hline \multicolumn{2}{|c|}{$f_{\mathrm{m} 0.05}$} & & & & 39.56 & 34.40 \\
\hline
\end{tabular}


Comparison of moduly of elasticity obtained by non-destructive and destructive tests of timber samples

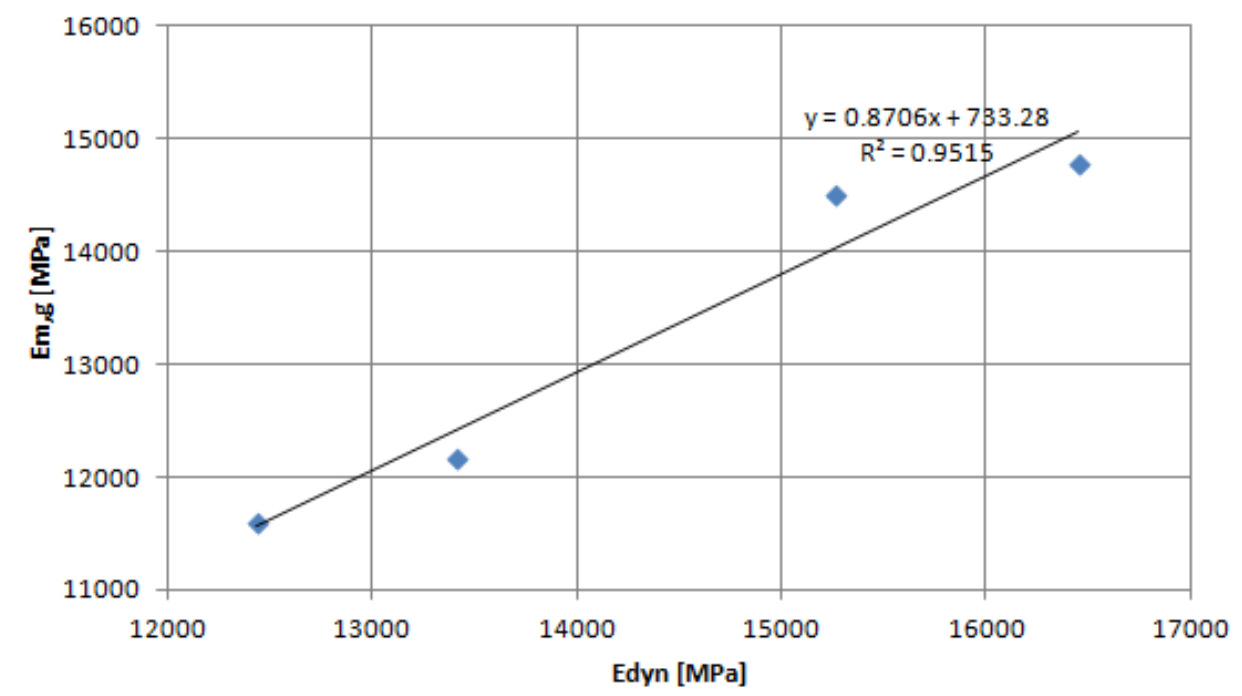

Figure 6 Regression of dynamic modulus of elasticity on static modulus of elasticity

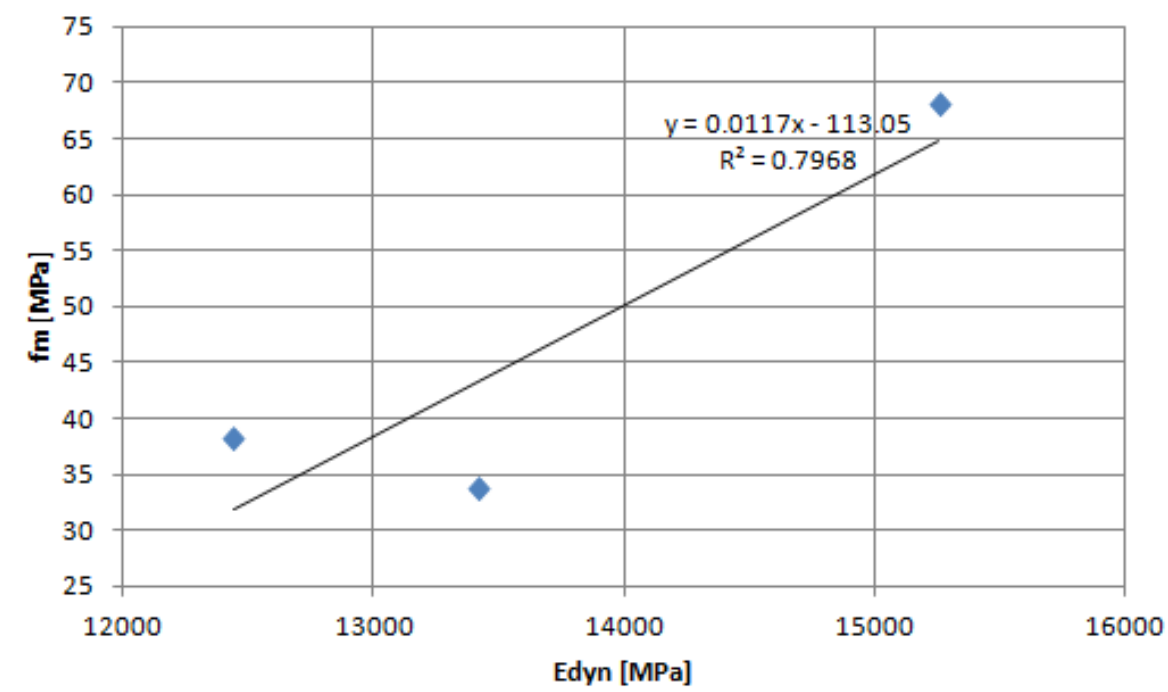

Figure 7 Regression of dynamic modulus of elasticity on bending strength

Table 7 Comparison of NDT and DT methods for specimens D5-D7

\begin{tabular}{|c|c|c|c|c|c|c|}
\hline Spec. & $\begin{array}{l}\text { Density } \\
{\left[\mathrm{kg} / \mathrm{m}^{3}\right]}\end{array}$ & $\begin{array}{c}\text { SWS - L } \\
\text { Avg. }\end{array}$ & $\begin{array}{c}E_{\text {dyn }} \\
{[\mathrm{MPa}]}\end{array}$ & $\begin{array}{r}E_{\mathrm{m}, \mathrm{g}} \\
{[\mathrm{Mpa}]}\end{array}$ & $\begin{array}{l}\text { Bending strength } \\
\quad f_{\mathrm{m}}[\mathrm{MPa}]\end{array}$ & $\begin{array}{c}\text { Corrected } \\
\text { bending strength } \\
f_{\mathrm{m}}[\mathrm{MPa}]\end{array}$ \\
\hline D5 & 389.0 & 5021.00 & 9807.10 & 9104.13 & 32.22 & 25.37 \\
\hline D6 & 429.0 & 5545.50 & 13194.57 & 10999.29 & 44.98 & 35.42 \\
\hline D7 & 459.4 & 5949.00 & 16259.87 & 15434.73 & 75.51 & 59.45 \\
\hline \multicolumn{2}{|c|}{ Average } & 5505.17 & 13087.18 & 11846.05 & 50.90 & 40.08 \\
\hline \multicolumn{2}{|c|}{ St. dev. } & 465.31 & 3227.72 & 3249.14 & 22.24 & 17.51 \\
\hline \multicolumn{2}{|c|}{ CV } & 0.085 & 0.247 & 0.274 & 0.437 & 0.437 \\
\hline \multicolumn{2}{|c|}{$f_{\mathrm{m} 0.05}$} & & & & 33.50 & 26.38 \\
\hline
\end{tabular}

Table abbreviations:

$b=$ width of cross-section; $h=$ height of cross-section; $I=$ length of cross-section; Parallel = parallel to the grain; Perp. = perpendicular to the grain; Rad. = radial to the grain; SWS $-\mathrm{L}=$ stress wave speed longitudinal to the grain; $S W S-T=$ stress wave speed transversal to the grain; SWS $-\mathrm{R}=$ stress wave speed radial to the grain 


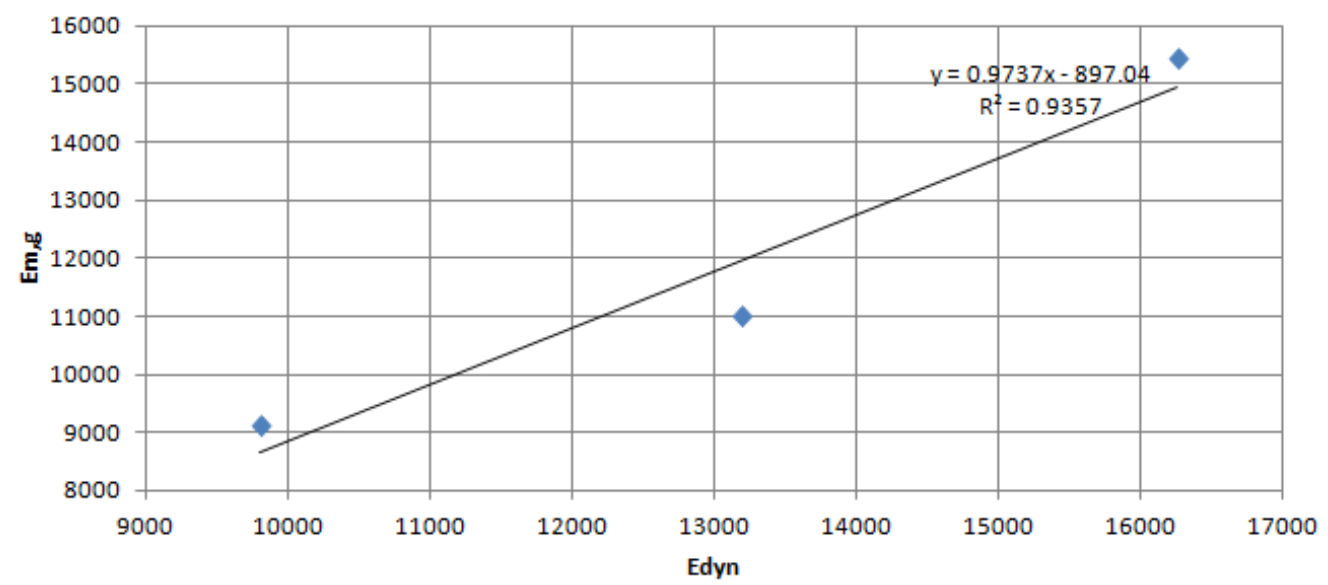

Figure 8 Regression of dynamic modulus of elasticity on static modulus of elasticity

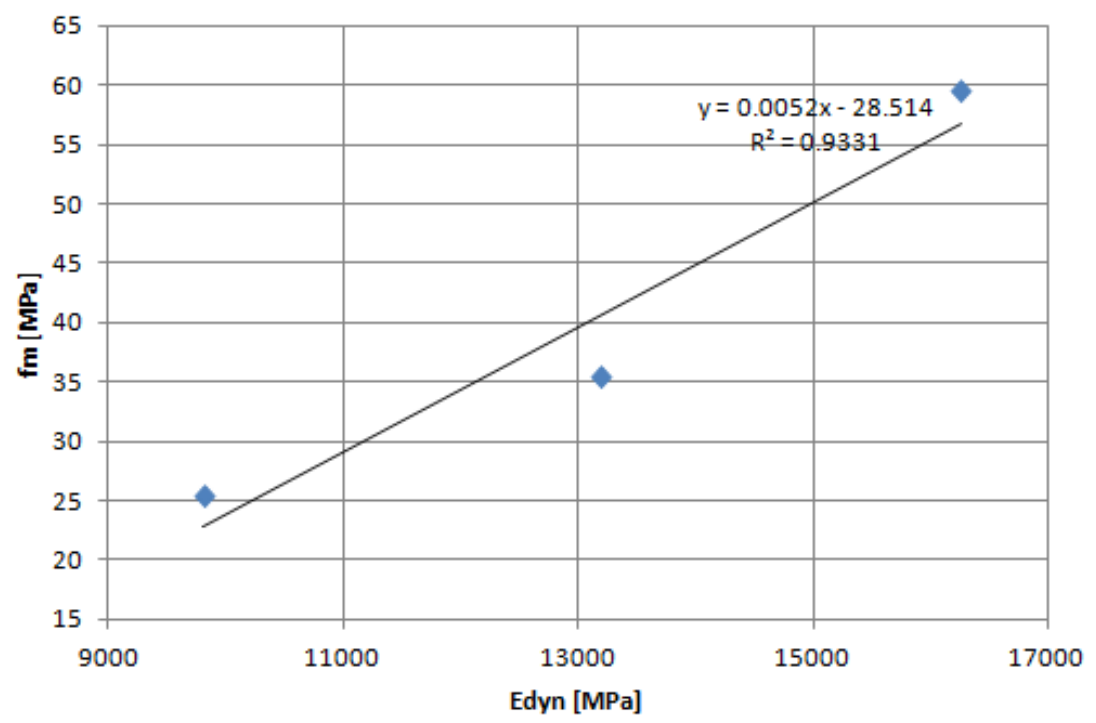

Figure 9 Regression of dynamic modulus of elasticity on bending strength

We correlated the static and dynamic moduli of elasticity, as shown in Table 8. The static and dynamic modulus of elasticity correlate well and have a high regression coefficient $\left(R^{2}=0.95\right.$ for laminated timber samples; $R^{2}=0.94$ for timber).

Table 8 Comparison of experimental results and EN [4]

\begin{tabular}{ccccc} 
GL28h & $\mathrm{E}_{0, \text { mean }}$ & $\mathrm{E}_{0,05}$ & $\mathrm{f}_{\mathrm{m}, \mathrm{k}}$ & $\mathrm{f}_{\mathrm{c}, 0, \mathrm{k}}$ \\
\hline Experimental results: & 13263.32 & 11686.60 & 34.40 & 46.79 \\
\hline EN 1194: & 12600.00 & 10200.00 & 28.00 & 26.50 \\
C24 & $\mathrm{E}_{0, \text { mean }}$ & $\mathrm{E}_{0,05}$ & $\mathrm{f}_{\mathrm{m}, \mathrm{k}}$ & $\mathrm{f}_{\mathrm{c}, 0, \mathrm{k}}$ \\
Experimental results: & 11846.05 & 9293.64 & 26.38 & 50.64 \\
\hline EN 338: & 11000.00 & 7400.00 & 24.00 & 21.00 \\
\hline
\end{tabular}

Our experimental bending strength was slightly higher than the values presented in EN 1194 [5] and EN 338 [6], likely because of the small number of specimens. Our results of compression parallel to grains revealed much higher strength values than in the standards. 
If no data for the relevant properties of structure-size specimens are available, then the necessary characteristic values are determined from the characteristic values for bending strength, mean modulus of elasticity, and density. EN 384 [4] gives approximate values for the other parameters according to the mean modulus of elasticity, density, and characteristic bending strength, as shown in Table 9.

Table 9 Approximate values for other characteristic parameters calculated from the mean modulus of elasticity, density, and characteristic bending strength (EN 384) [4]

\begin{tabular}{|c|c|c|}
\hline & Softwood & Glulam \\
\hline$f_{m, k}$ & $=26.38 \mathrm{~N} / \mathrm{mm}^{2}$ & $=34.4 \mathrm{~N} / \mathrm{mm}^{2}$ \\
\hline$E_{0, \text { mean }}$ & $=11846.05 \mathrm{~N} / \mathrm{mm}^{2}$ & $=13263.32 \mathrm{~N} / \mathrm{mm}^{2}$ \\
\hline$\rho_{k}$ & $=425.84 \mathrm{~kg} / \mathrm{m}^{3}$ & $=452.81 \mathrm{~kg} / \mathrm{m}^{3}$ \\
\hline $\mathrm{f}_{\mathrm{t}, 0, \mathrm{k}}=0.6 \times \mathrm{f}_{\mathrm{m}, \mathrm{k}}$ & $=15.83 \mathrm{~N} / \mathrm{mm}^{2}$ & $=20.64 \mathrm{~N} / \mathrm{mm}^{2}$ \\
\hline$f_{c, 0, k}=5 \times f_{m, k} 0^{0.45}$ & $=21.80 \mathrm{~N} / \mathrm{mm}^{2}$ & $=24.57 \mathrm{~N} / \mathrm{mm}^{2}$ \\
\hline$f_{v, k}=\operatorname{MIN}\left(3.8 ; 0.2 \times f_{m, k} k^{0.8}\right)$ & $=2.74 \mathrm{~N} / \mathrm{mm}^{2}$ & $=3.39 \mathrm{~N} / \mathrm{mm}^{2}$ \\
\hline $\mathrm{f}_{\mathrm{t}, 90, \mathrm{k}}=\operatorname{MIN}\left(0.6 ; 0.0015 \rho_{\mathrm{k}}\right)$ & $=0.60 \mathrm{~N} / \mathrm{mm}^{2}$ & $=0.60 \mathrm{~N} / \mathrm{mm}^{2}$ \\
\hline$f_{c, 90, k}=0.007 \rho_{k}$ & $=2.98 \mathrm{~N} / \mathrm{mm}^{2}$ & $=3.17 \mathrm{~N} / \mathrm{mm}^{2}$ \\
\hline $\mathrm{E}_{0.05}=0.67 \mathrm{E}_{0, \text { mean }}$ & $=7936.85 \mathrm{~N} / \mathrm{mm}^{2}$ & $=8886.42 \mathrm{~N} / \mathrm{mm}^{2}$ \\
\hline$E_{90 \text {,mean }}=E_{0, \text { mean }} / 30$ & $=394.86 \mathrm{~N} / \mathrm{mm}^{2}$ & $=422.11 \mathrm{~N} / \mathrm{mm}^{2}$ \\
\hline $\mathrm{G}_{\text {mean }}=\mathrm{E}_{0, \text { mean }} / 16$ & $=740.37 \mathrm{~N} / \mathrm{mm}^{2}$ & $=828.96 \mathrm{~N} / \mathrm{mm}^{2}$ \\
\hline
\end{tabular}

\section{CONCLUSION}

In this paper, we experimentally assessed various timber specimens using non-destructive and destructive tests to obtain their dynamic and static moduli of elasticity. We subjected timber specimens to a four-point bending test and calculated their static modulus of elasticity according to HRN EN 408 [1]. The modulus of elasticity, bending strength, and compressive strength parallel to the grains were calculated according to EN 384 [4]. The dynamic modulus of elasticity was obtained with an ultrasonic NDT that measured the peak acceleration of sound.

From these results, we conclude that, when destructive methods cannot be used to measure the properties of timber elements, dynamic properties appear to be useful for evaluating their properties. In particular, we provided a good linear regression that relates the dynamic and static moduli of elasticity in bending; from that correlation, one can approximate the static modulus of elasticity from the dynamic modulus of elasticity obtained by NDTs. This process makes it possible to determine all other timber characteristics according to EN 384 [4] without destroying the sample.

\section{References}

[1] HRN EN 408:2011: Timber structures - Structural timber and glued laminated timber

[2] Faggiano, B. et al.: Combined non-destructive and destructive tests for the mechanical characterization of old structural timber elements, peer.berkeley.edu, 13 Mar 2013.

[3] Course in Non-Destructive Testing of Wood, www.aq.upm.es, 15 Mar 2013.

[4] EN 384:2010: Structural timber - Determination of characteristic values of mechanical properties and density

[5] EN 1194:1999: Timber structures - Glued laminated timber - Strength classes and determination of characteristic values

[6] EN 338:2009: Structural timber - Strength classes 